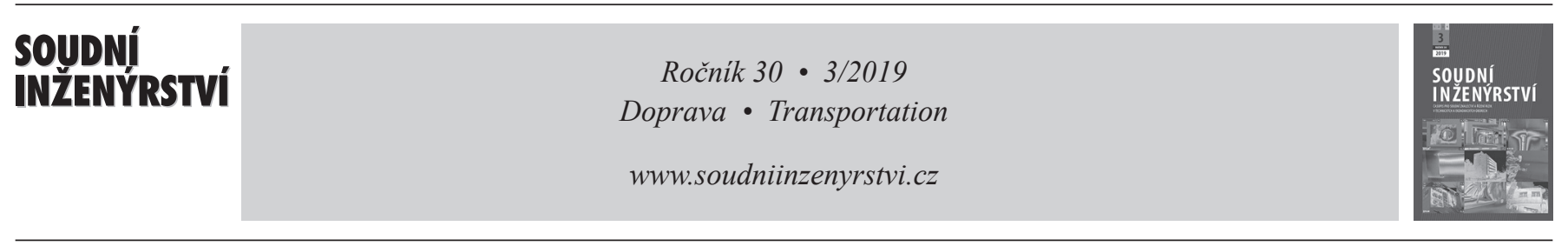

\title{
Úvod do problematiky zjišt'ování příčin požárů osobních vozidel
}

\author{
Introduction to the Investigations of the Fire Causes of the Vehicles
}

\author{
Michal Martínek*
}

Škoda-Auto a. s

\begin{abstract}
Abstrakt
Požáry osobních vozidel představují zásadní hledisko pro uživatele, výrobce, bezpečnost dopravy a environmentální prostředí. Je možné takto požár vozu specifikovat jako mimořádnou událost a je nutné správně definovat př́ičinu jeho vzniku. I když vyšetřování požárů vozidel je často považováno za složité a obtížné, požáry vozidel mají základní fyzikální požadavky pro vznícení a následné vyšetřovací metody $\mathrm{k}$ úspěšnému nalezení příčiny. Tento př́spěvek pojednává o různých aspektech vzniku požáru osobního vozu, základním pojmům a metod k zjišt'ován příčiny. Příspěvek byl prezentován na konferenci ExFoS 2019 ve dnech 24.-25. ledna 2019.
\end{abstract}

Klíčová slova: požár vozu, vyšetřování požáru, zdroj požáru, vzory požáru, detekce akcelerantů hoření.

\section{1. ÚVOD}

Obecně, zjišstování př́ičin vzniku požárů je součástí výkonu státního požárního dozoru, vyplývajícího z ustanovení § 26 odst. 2 písm. b) a $\S 31$ odst. 1 písm. f) zákona č. 133/1985 Sb., o požární ochraně, ve znění pozdějších předpisů. Vlastním vyšetřováním požárů se rozumí souhrn úkonů a postupů, směřujících ke zjištění př́iciny vzniku požáru a jeho rozšíření, které se ve všeobecné úrovni řídí ustanovením $§ 50$ vyhlášky č. 246/2001 Sb., o stanovení podmínek požární bezpečnosti a výkonu státního požárního dozoru (vyhláška o požární prevenci).

Jedná se o obecnou činnost vykonávanou v rámci státního požárního dozoru. V rámci České republiky vlastní výkon vyšetřování požárů provádí jednotlivé strukturální složky Hasičského záchranného sboru, příslušník pro zjištění příčiny vzniku požáru tzv. vyšetřovatel požáru. Vyšetřovatel požáru zpravidla vyjiždí na místo události, na místě události vyšetřovatel požárů provádí vyšetřování za účelem zjištění př́íčiny vzniku požáru a šíření požáru, případně zjištění porušení předpisů, zajišt’uje listinnou dokumentaci, pořizuje fotodokumentaci a dokumentaci

\begin{abstract}
Vehicle fires are major considerations for users, manufacturers, vehicle safety and for the environment. The vehicle fire can be as an extraordinary event specified and it is necessary to define correctly the cause of its occurrence. Although vehicle fire investigations are often considered complicated, vehicle fires, have basic physical requirements for an ignition and subsequent investigation methods to identify a cause successfully. This article deals with the different aspects of the vehicle fire, the basic concepts and methods of determining the causes. The paper was presented at the ExFoS 2019 conference, 24-25 ${ }^{\text {th }}$ January.
\end{abstract}

Keywords: vehicle fire, fire investigation, fire source, fire pattern, fuel accelerants detection.

audiovizuální. Vyšetřovatel požárů může v odůvodněných případech žádat o spolupráci Technický ústav požární ochrany, chemické laboratoře a orgány Policie ČR. Spolupráce probíhá na základě Dohody o součinnosti mezi Hasičským záchranným sborem ČR a Policí ČR. Ke spolupráci může být přizván další orgán státní správy nebo jiné osoby s potřebnou odborností. [1,2]

V rámci zjišt'ování příčin požárů souvisí i hledání a určení vzniku požárů osobních vozidel kategorie M1, kterým se věnuje tento článek. K určení konkrétní příčiny v takovýchto případech je součástí vyjádření expertizního pracoviště, výrobce vozu nebo znalecký posudek soudního znalce. Expertíza v takovém případě probíhá již mimo místo události na základě dostupných informací a analýzy vozu, popř. jeho součástí.

Zveřejněná statistická ročenka Hasičského záchranného sboru ČR za rok 2017 uvádí požáry dopravních prostředků a pracovních strojů, jako třetí nejčastější výskyt požárů a vzniklých škod (obr. 1).

U zveřejněného článku z roku 2014 [3] por. Bc. Ing. Vladimíra Hacsiková mluvčí HZS Olomouckého kraje zmiňuje: „Nejčastější př́ičinou vzniku požáru u vozidel bývá technická závada na elektroinstalaci, netěsnost palivové soustavy (a to i u aut 


\begin{tabular}{|c|c|c|c|c|c|c|c|c|}
\hline \multirow[b]{2}{*}{ Budova, objekt } & \multirow[b]{2}{*}{ Počet } & \multirow[b]{2}{*}{$\underset{\%}{\text { Index }}$} & \multirow[b]{2}{*}{$\begin{array}{l}\text { Škoda } \\
\text { v mil. KČ }\end{array}$} & \multirow[b]{2}{*}{$\underset{\%}{\operatorname{Index}}$} & \multirow[b]{2}{*}{$\begin{array}{l}\text { Uchráněné } \\
\text { hodnoty } \\
\text { v mil. Ké }\end{array}$} & \multicolumn{2}{|c|}{ Usmrceno } & \multirow[b]{2}{*}{$\begin{array}{l}\frac{0}{2} \\
\frac{5}{5} \\
\text { N }\end{array}$} \\
\hline & & & & & & 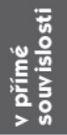 & $\begin{array}{l}\frac{E}{8} \\
\frac{8}{8}\end{array}$ & \\
\hline budovy občanské výstavby, včetně budov pro dopravu a spoje & 711 & 130 & 320,33 & 119 & 879,25 & 5 & 6 & 117 \\
\hline bytový domovní fond & 1514 & 97 & 106,97 & 95 & 742,02 & 13 & 16 & 432 \\
\hline rodinné domky a ostatní budovy pro bydlení & 1675 & 91 & 280,07 & 106 & 1210,50 & 13 & 19 & 297 \\
\hline budovy a haly pro výrobu a služby & 369 & 104 & 1810,01 & 150 & 3078,54 & 1 & 2 & 99 \\
\hline energetické výrobni budovy & 79 & 81 & 214,36 & 120 & 506,23 & 0 & 1 & 13 \\
\hline budovy a objekty pro garážování & 99 & 108 & 56,87 & 207 & 116,28 & 1 & 1 & 19 \\
\hline budovy pro skladování (bez zemědělských) & 70 & 97 & 90,23 & 21 & 184,27 & 1 & 1 & 10 \\
\hline budovy pro skladování zemědělských produktů & 40 & 95 & 80,35 & 356 & 74,62 & 0 & 0 & 4 \\
\hline budovy pro rostlinou a živočišnou výrobu & 33 & 100 & 7,95 & 38 & 205,23 & 0 & 0 & 4 \\
\hline objektyv zemědělství & 13 & 144 & 1,85 & 36 & 21,47 & 0 & 0 & 0 \\
\hline objekty mimo budovy (bez zemědĕlských) & 150 & 99 & 51,28 & 28 & 597,71 & 1 & 1 & 6 \\
\hline objekty ve výstavbĕ a rekonstrukci & 38 & 86 & 25,73 & 296 & 77,83 & 0 & 0 & 10 \\
\hline provizoria a účelové objekty u budov & 469 & 97 & 38,30 & 27 & 164,23 & 5 & 7 & 53 \\
\hline dopravni prostředky a pracovni stroje & 2035 & 102 & 496,26 & 124 & 1252,50 & 4 & 21 & 188 \\
\hline zemědělské plochy a přirodni prostředí & 603 & 119 & 24,27 & 148 & 152,03 & 0 & 0 & 11 \\
\hline lesy & 966 & 108 & 6,26 & 116 & 85,08 & 2 & 2 & 9 \\
\hline volné skladovací plochy & 2513 & 123 & 11,43 & 139 & 58,85 & 0 & 0 & 21 \\
\hline demolice, skládky odpadu & 4384 & 99 & 22,29 & 71 & 153,50 & 2 & 3 & 37 \\
\hline ostatní & 996 & 94 & 8,32 & 15 & 114,22 & 9 & 12 & 62 \\
\hline
\end{tabular}

Obr. 1 Statistická ročenka 2017 - Požáry a škody podle mista vzniku (zdroj: https://www.hzscr.cz/clanek/statisticke-rocenky-hasicskehozachranneho-sboru-cr.aspx).

Fig. 1 Statistical Yearbook 2017 - Fires and damage by place of origin (source: https://www.hzscr.cz/clanek/statisticke-rocenky-hasicskehozachranneho-sboru-cr.aspx).

na alternativní pohon $\mathrm{LPG}$ ) a v neposlední řadě nedbalost provozovatelů, at’ při vlastní jízdě, údržbě nebo opravách automobilů. K dalším příčinám můžeme zařadit požáry způsobené dopravními nehodami a úmyslným zapálením.“ Však v mnoha případech analýzy konkrétní přičiny vzniku požáru osobních vozidel, je shledáván vliv vnějších faktorů na konkrétním viníku vzniklé události.

Objektivním pohledem činnost určení příčiny vzniku požáru vozu se stává multioborovou disciplínou, vzhledem k neustálému vývoji použité technologie vozů, vývoji v oblasti chemických látek, techniky a vědy atd.

\section{ZJIŠŤOVÁNÍ PŘíČIN POŽÁRŮ OSOBNÍCH VOZIDEL}

Zjišt'ování konkrétní příčiny požáru osobního automobilu je soubor činností a metod k určení ložiska požáru a jeho vzniku. Samotná expertíza vzniká prakticky v době již po vzniku události a provedení hasebních prací. S odstupujícím časem některé technické důkazy v závislosti na rozsahu poškození vozu zanikají. Základním aspektem k zjištování prríčin požárů osobních vozidel je získání dostatek dostupných informací, nastalých faktorů před vznikem události a popř. i informace o průběhu požáru. Př́ikladem základní vyžadované informace:

Tab. 1 Základní plán vyšetřování požáru motorového vozidla. [4]

Tab. 1 Planning the Investigation of a Motor Vehicle Fire. [4]

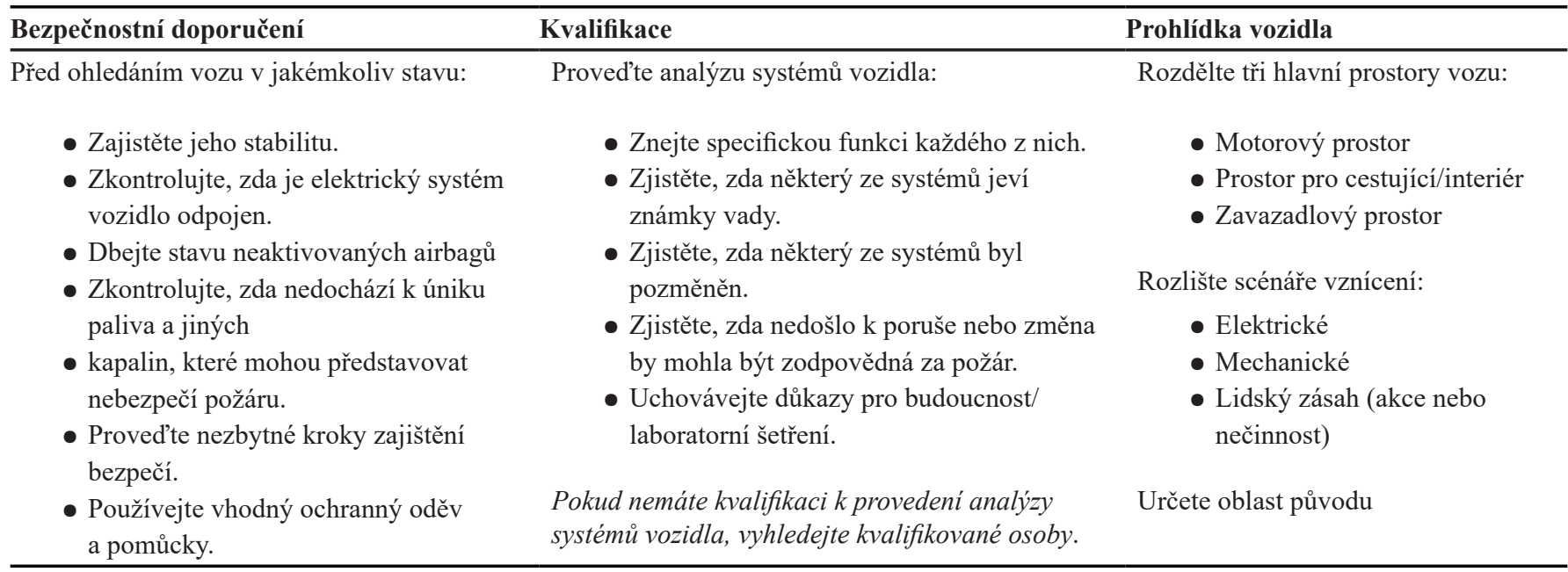


- poslední užití vozu a kým,

- stav kilometrů v době události,

- předchozí obsluhy nebo problémy,

- historie oprav a servisních údržby,

- poslední tankování - kde, kdy, atd.,

- dodatečné vybavení vozu a instalace,

- zásahy na dílech a částech vozu,

- fotodokumentace, videozáběry před/po požáru

\subsection{Základní pojmy}

\subsubsection{Oohledání vozu}

Pro nalezení a určení př́činy požáru osobního vozu je v mnoha případech nutné provedení technické analýzy a ohledání vozu popř. jeho součástí. Před provedením ohledání vozu je nutné vytvořit podmínky a stanovit základní faktory pro vyšetření vozidla po požáru viz. tab. 1 .

\subsubsection{Průběh požáru vozu, zdroj vznícení}

Zdroje možnosti vznícení u vozidel jsou stejné jako zdroje spojené se strukturou požárů. Otevřené plameny, mechanické či elektrické poruchy a kuřácké potřeby mohou často vést $\mathrm{k}$ požáru vozidla. Vozidla mají některé jedinečné možnosti zdroje přičiny vznícení, které by měly být zváženy a vyhodnoceny, včetně horkých výfukových systémů, dílů podléhající tření apod. [4]

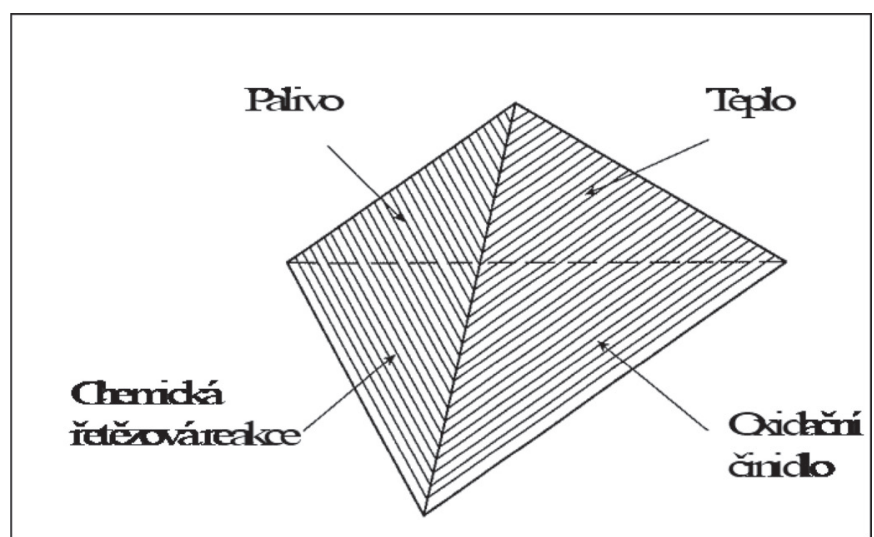

Obr. 2 Požární čtyřstěn. [5]

Fig. 2 Fire Tetrahedron. [5]

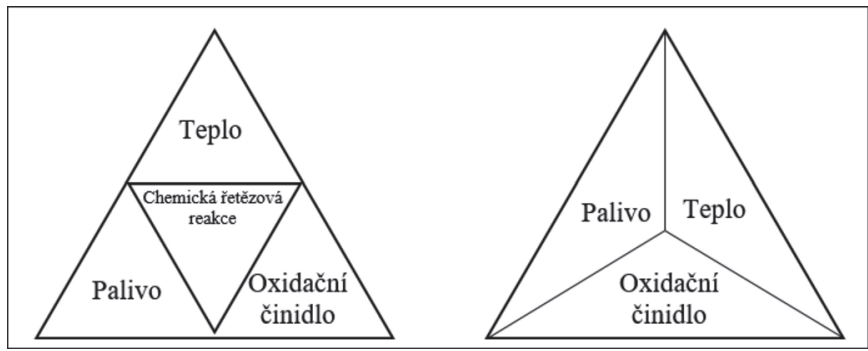

Obr. 3 Požárni čtyřstěn a trojúhelník (zdroj: Ron Hopkins, CFEI, CVFI, CFPS TRACE Fire Protection and Safety Consultants, Ltd. Richmond, Kentucky).

Fig. 3 Fire Tetrahedron and Triangle (source: Ron Hopkins, CFEI, CVFI, CFPS TRACE Fire Protection and Safety Consultants, Ltd. Richmond, Kentucky).
Osobní vozidel lze uvažovat jako zapouzdřenou konstrukci, která má oddělené prostory. Proto požár vozu je rozdělen do několika prostorů:

- požár v přední části vozu,

- požár v interiéru vozu,

- požár v zadní části vozu.

Dále je nutné uvažovat poškození vozu vlivem požáru i mimo samotnou vnitřní konstrukci, jakožto přenos tepla, požár pod vozidlem apod.

K vzniku požáru musí, nastav stav spalovací reakce, ta může být charakterizována čtyřmi složkami: palivem, oxidačním činidlem, teplem a neinhibovanou chemickou řetězovou reakcí. Tyto čtyři komponenty jsou klasicky symbolizovány čtyřstrannou pevnou geometrickou formou nazývanou čtyřstěn (obr. 2). Požáry je možné zabránit nebo potlačit ovládáním nebo odstraněním jedné nebo více stran čtyřstěnu (obr. 3). [5]

Průběh požáru je dán na rychlosti uvolňování tepla. Rychlost uvolňování tepla $\mathrm{Q}(\mathrm{kW})$ popisuje míru růstu a velikost požáru. Základní vzorec se stanovuje:

$$
\mathrm{Q}=\mathrm{m}^{*} \mathrm{~A} \Delta \mathrm{H}_{c}[5],
$$

kde:

m“ $\quad\left(\mathrm{kg} / \mathrm{m}^{2} \times \mathrm{s}\right)$ představuje úbytek hmoty,

A $\quad\left(\mathrm{m}^{2}\right)$ postiženou oblast,

$\Delta \mathrm{H}_{\mathrm{c}} \quad(\mathrm{kJ} / \mathrm{kg})$ spalné teplo paliva, které je odlišná pro jednotlivé druhy paliva a tabulkována.

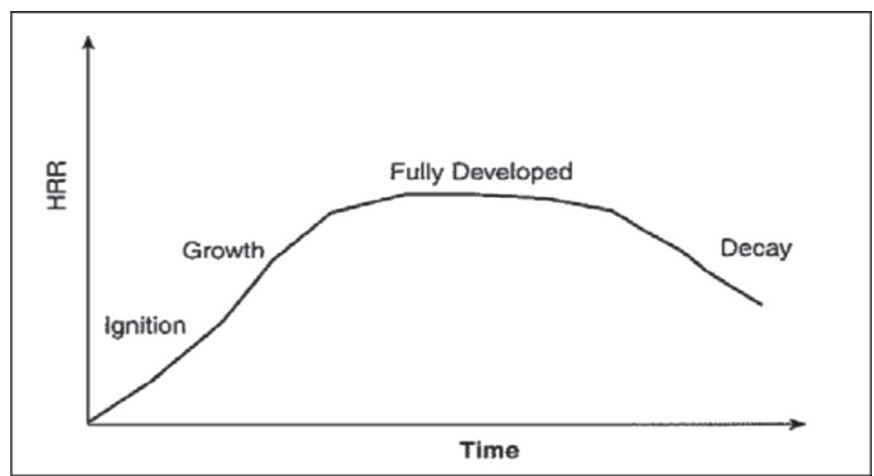

Obr. 4 Idealizovaná křivka rychlosti uvolňování tepla-požár řizen palivem. [5]

Fig. 4 Idealized heat release rate curve for a fuel-controlled fire. [5]

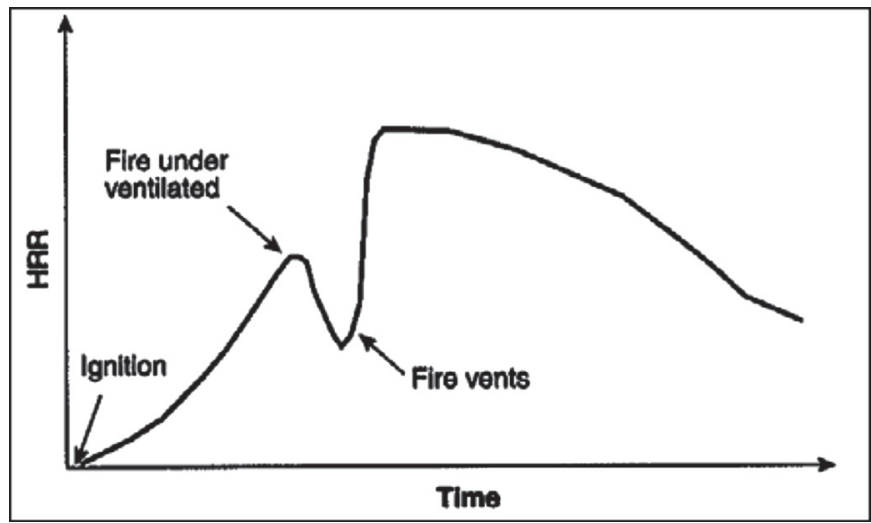

Obr. 5 Idealizovaná křivka rychlosti uvolňování tepla-požár řizen palivem. [5]

Fig. 5 Idealized heat release rate curve for a fuel-controlled fire. [5] 


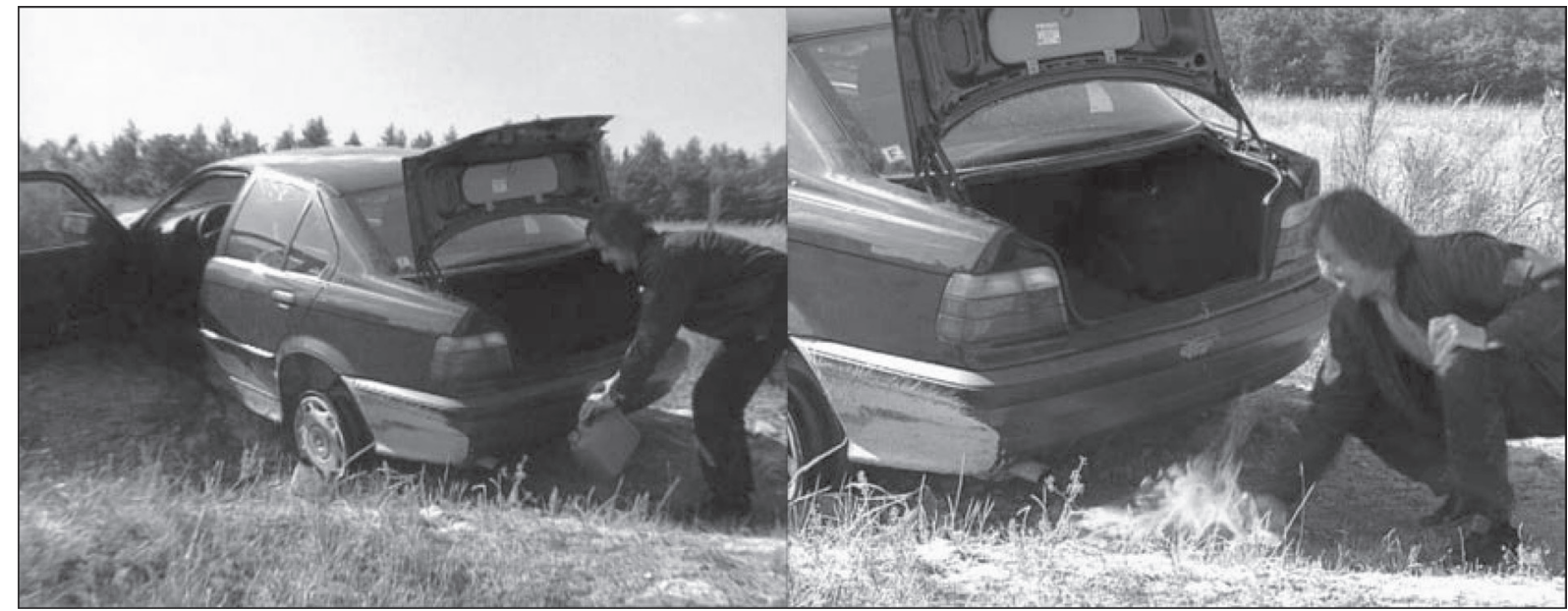

Obr. 6 Výstřižek z videa (zdroj: Gesamtverbrand der Deutschen Versicherungswirtschaft e.V.).

Fig. 6 Video snapshot (source: Gesamtverbrand der Deutschen Versicherungswirtschaft e.V.).

Hodnota rychlosti uvolňování tepla ovlivňuje průběh teploty plynů v čase. Fáze rozvoje, kdy z požáru malých rozměrů vzniká požár rozsáhlý, je závislá na množství kyslíku dostupného při hoření. Při dostatečném př́stupu kyslíku do místa hoření je rychlost uvolňování tepla ovlivněna množstvím požárního zatížení v požárním úseku - požár řízen palivem (obr. 4). V př́ípadě malých ploch otvorů obvodových konstrukcí je rychlost uvolňování tepla ovlivněna nedostatečným množstvím kyslíku pro hoření - požár řízen ventilací (obr. 5). U obou případů dochází $\mathrm{k}$ razantnímu nárůstu rychlosti uvolňování tepla po celkovém vzplanutí. Tento okamžik určuje přechod mezi lokálním a prostorovým požárem, který pohltí veškeré hořlavé materiály požárního úseku. [5, 6]

\subsubsection{Ložisko požáru}

$\mathrm{Na}$ základě rozdělení zasaženého prostoru požárem a stanovení průběhu požáru je nutné určit ložisko požáru a zdroj vznícení.

\subsection{Technické faktory zdroje požáru vozidel}

Dle charakteru rychlosti uvolňování tepla a průběhu požárního děje nemusí v značně prípadech nejvíce zasažená oblast odpovídat však zdroji vznícení. V takovém př́ípadě záleží na množství a přístupu paliva a vzduchu. V některých kritických případech může být i samotný zdroj a iniciátor požáru v průběhu požáru zničen nebo se může nacházet vně samotného vozu. Zvláště v mnoha př́padech, kdy se jedná o netechnický faktor (obr. 6).

$\mathrm{K}$ základním informacím o průběhu požáru a $\mathrm{k}$ dané událostí patří i ověření technického stavu vozidlo v době určování př́ičiny k ověření podaných informací, zejména zda došlo $\mathrm{k}$ události při jízdě, nebo u odstaveného vozidla, tj. např. stav zámků dveří, zapalovací skřriňky apod.

\subsubsection{Pohonné hmoty}

V současné době vozidla se spalovacím motorem spadají do dvou základních kategorií na pohon na kapalná paliva, plynná paliva, popř. jejich kombinace. Jakmile se oheň začne vyvíjet, může se některá z těchto paliv vznítit, což vytváří škody, které se mohou obtížně oddělit od těch, které vznikly při spalování původně vznětlivých materiálů, což komplikuje úlohu oddělit primární od sekundárních poškození. Kromě benzínu a motorové nafty, osobní vozidla obsahují další hořlavá média, jako např. maziva motoru, převodové maziva, kapaliny posilovače řízení, chladicí kapaliny a brzdové kapaliny atd. Mnoho z těchto paliv je př́tomno ve většině vozidel. Zapalovací potenciál těchto paliv závisí na vlastnostech každého paliva, fyzickém stavu paliva (kapalné, rozprašované nebo rozprašované formě) a povaze zdroje vznícení. [4]

V tomto smyslu, je nutné uvažovat i zápalné podmínky před a v průběhu požáru, přehledné hodnoty jsou znázorněny v tabulce (obr. 7).

Plynná paliva pro motorová vozidla jsou běžně zkapalněný/ stlačený ropný plyn nebo zemní plyn. Tabulka (obr. 8) uvádí vlastnosti plynných paliv v motorových vozidlech.

K požárům v souvislosti s netěsností palivové soustavy dochází především při jízdě (uvolnění benzinového vedení, uvolnění vstřiků apod.). Však pro inicializaci unikajícího paliva potažmo jiných hořlavých médií vozu musí být splněny mnohé podmínky stavu spalovací reakce tj. teplo, přísun vzduchu...

\subsubsection{Elektrické systémy vozu}

Př́ičinou požáru vozu v rámci elektrické soustavy vozu, v rámci soustavy $12 \mathrm{~V}$, je možnou prŕíčinou elektrický zkrat v souvislosti s proudovým přetížením použitých vodičů elektroinstalace vozu. K požáru od elektrické instalace dochází zpravidla při jízdě poškození izolace elektrických vodičů a následný kontakt s kovovými zemnícími částmi, u odstaveného vozidla se jedná o sporadickou prríčinu vlivem nehybnosti celé soustavy a vozu. V rámci kritického poškození vozu je nutné rozlišovat primární a sekundární následky zkratu. Zároveň fyzikální podobu jejich vzniku v průběhu požáru (obr. 9).

Požár vozu nebo jeho části může být zároveň inicializován lokálním přechodovým odporem na elektrické soustavě, popř. jiskřením volných spojů.

\subsubsection{Horké povrchy}

Komponenty výfukového systému mohou zajistit dostatečnou teplotu pro inicializaci a vznícení hořlavých materiálů. Prokluz součástí převodovky resp. spojkového setu může mít za následek dostatečné teplo, k teplenému namáhání okolních dílů. Motorový olej, kapalina posilovače řízení a brzdová kapalina se mohou rovněž zapálit, když jsou v kontaktu s díly vytápěného výfukového 


\begin{tabular}{|c|c|c|c|c|c|c|c|c|c|c|c|}
\hline \multirow[b]{3}{*}{ Liquid } & \multirow{2}{*}{\multicolumn{2}{|c|}{ Flash Point ${ }^{a}$}} & \multirow{2}{*}{\multicolumn{2}{|c|}{$\begin{array}{l}\text { Autoignition } \\
\text { Temperature }^{\text {b }}\end{array}$}} & \multicolumn{2}{|c|}{$\begin{array}{l}\text { Flammability } \\
\text { Limits }^{c}\end{array}$} & \multicolumn{4}{|c|}{ Boiling Point ${ }^{d}$} & \multirow{3}{*}{$\begin{array}{c}\begin{array}{c}\text { Vapor } \\
\text { Density }\end{array} \\
(\text { Air }=1)\end{array}$} \\
\hline & & & & & \multirow{2}{*}{$\begin{array}{c}\text { LFL } \\
\%\end{array}$} & \multirow{2}{*}{$\begin{array}{c}\text { UFL } \\
\%\end{array}$} & \multicolumn{2}{|c|}{ IBP } & \multicolumn{2}{|c|}{ FPB } & \\
\hline & ${ }^{\circ} \mathbf{C}$ & ${ }^{\circ} \mathbf{F}$ & ${ }^{\circ} \mathbf{C}$ & ${ }^{\circ} \mathbf{F}$ & & & ${ }^{\circ} \mathbf{C}$ & ${ }^{\circ} \mathbf{F}$ & ${ }^{\circ} \mathrm{C}$ & ${ }^{\circ} \mathbf{F}$. & \\
\hline Gasoline & $\begin{array}{r}-45 \text { to } \\
-40\end{array}$ & $\begin{array}{r}-49 \text { to } \\
-40 \\
\end{array}$ & $350-460$ & $660-860$ & 1.4 & 7.6 & $26-49$ & $78-120$ & $171-233$ & $339-452$ & $3-4$ \\
\hline $\begin{array}{l}\text { Diesel fuel } \\
\text { (fuel oil \#2) }\end{array}$ & $38-62$ & $100-145$ & $254-260$ & $489-500$ & 0.4 & 7 & 127-232 & $260-450$ & $357-404$ & $675-760$ & $5-6$ \\
\hline Brake fluid & $110-171$ & $230-340$ & $300-319$ & $572-606$ & 1.2 & 8.5 & 232-288 & $111-142$ & $460-550$ & 238-288 & $5-6$ \\
\hline $\begin{array}{l}\text { Power steering } \\
\text { fluid }\end{array}$ & $175-180$ & $347-356$ & $360->382$ & $680->720$ & 1 & 7 & $309-348$ & $588-658$ & $507-523$ & $945-973$ & $>1$ \\
\hline Motor oil & $200-280$ & $392-536$ & $340-360$ & $644-680$ & 1 & 7 & 299-333 & $570-631$ & $472-513$ & $882-955$ & $>1$ \\
\hline Gear oil & $150-270$ & $302-510$ & $>382$ & $>716$ & 1 & 7 & $316-371$ & $601-700$ & $>525$ & $>977$ & $>1$ \\
\hline $\begin{array}{l}\text { Automatic } \\
\text { transmission } \\
\text { fluid }\end{array}$ & $150-280$ & $302-536$ & $330->382$ & $626->716$ & 1 & 7 & 239-242 & $462-468$ & $507-523$ & $945-973$ & $>1$ \\
\hline $\begin{array}{l}\text { Ethylene glycol } \\
\text { (antifreeze) }\end{array}$ & $110-127$ & 230-261 & $398-410$ & $748-770$ & 3.2 & 15.3 & 196-198 & $385-388$ & & & 2.1 \\
\hline $\begin{array}{l}\text { Propylene } \\
\text { glycol } \\
\text { (antifreeze) }\end{array}$ & $93-107$ & $199-225$ & $371-421$ & $700-790$ & 2.6 & 12.5 & $187-188$ & $369-370$ & & & 2.6 \\
\hline $\begin{array}{l}\text { Methanol } \\
\text { (washer fluid) }\end{array}$ & $11-15$ & $52-55$ & $464-484$ & $867-903$ & 6 & 36 & 65 & 149 & & & 1.1 \\
\hline
\end{tabular}

Flash point data was obtained from technical data sheets and material safety data sheets from manufacturers and suppliers of the major brands of each type of fluid available in the United States. The flash points of gasolines reported in these sources were determined by ASTM D56, Standard Test Method for Flash Point by Tag Closed Tester. The flash points for diesel fuels, brake fluids, power steering fluids, motor oils, transmission fluids, gear oils, ethylene glycol (antifreeze), propylene glycol (antifreeze), and methanol were determined by ASTM D56, ASTM D92, Standard Test Method for Flash and Fire Points by Cleveland Open Cup Tester, or ASTM D93, Standard Test Method for Flash Point by Pensky-Martens Closed Cup Tester.

bAutoignition temperature data for gasoline, diesel fuel, brake fluid, ethylene glycol, propylene glycol, and methanol was obtained from technical data sheets and material safety data sheets from manufacturers and suppliers of the major brands of each type of fluid available in the United States. These sources generally did not report the test method used to determine autoignition temperature; however, ASTM E659, Standard Test Method for Autoignition Temperature of Liquid Chemicals, is the laboratory test method typically used to determine autoignition temperature. Autoignition temperature data for power steering fluid, motor oil, gear oil, and automatic transmission fluid were obtained using ASTM E659.

"Flammability limit data was obtained from technical data sheets and material safety data sheets from manufacturers and suppliers of the major brands of each in the United States. These sources generally did not specify the laboratory test method used to determine the reported flammability limits; however, ASTM E681, Standard Test Method for Concentration Limits of Flammability of Chemicals (Vapors and Gasses), is a laboratory test method typically used to determine the lower flammability limit (LFL) and the upper flammability limit (UFL).

${ }^{\mathrm{d} B}$ Boiling range data for gasolines was obtained from the Alliance of Automobile Manufacturers annual North American survey of gasoline properties for 2003. The boiling ranges reported in this survey were determined by ASTM D86, Standard Test Method for Distillation of Petroleum. Boiling range data for diesel fuel was obtained from technical data sheets and material safety data sheets from manufacturers and suppliers of the major brands of diese fuel in the Unites States. These sources generally did not report the laboratory test method used to determine the boiling range of diesel fuel. Boiling range data for brake fluid, power steering fluid, motor oil, gear oil, and automatic transmission fluid were determined by ASTM D2887, Standard Test Method for Boiling Range Distribution of Petroleum Fractions by Gas Chromatography. Boiling point data for ethylene glycol, propylene glycol, and methanol were obtained from material safety data sheets from manufacturers and suppliers of these chemicals. These sources did not report the laboratory test method used to determine boiling point. In the table IBP and FBP are initial boiling point and final boiling point, respectively.

eVapor density data was obtained from material safety data sheets from manufacturers and suppliers of these materials.

Studies include the following:

1. API PUBL 2216, Ignition Risk of Hydrocarbon Vapors by Hot Surfaces in the Open Air.

2. Arndt, S.M., Stevens, D.C., and Arndt, M.W., "The Motor Vehicle in the Post-Crash Environment, An Understanding of Ignition Properties of Spilled Fuels," SAE 1999-01-0086, International Congress and Exposition, Detroit, MI, March 1-4, 1999.

3. Colwell, J.D. and Reze, A. "Hot Surface Ignition of Automotive and Aviation Fluids," Fire Technology, Second Quarter 2005, pp. 105-123.

4. LaPointe, N.R., Adams, C.T., and Washington, J, "Autoignition of Gasoline on Hot Surfaces" Fire and Arson Investigator, Oct. 2005 : pp. 18-21.

Obr. 7 Vlastnosti zápalných kapalin. [5]

Fig. 7 Properties of ignitible liquids. [5]

\begin{tabular}{|c|c|c|c|c|c|c|c|c|}
\hline \multirow[b]{2}{*}{ Gas } & \multicolumn{2}{|c|}{$\begin{array}{l}\text { Autoignition } \\
\text { Temperature }\end{array}$} & \multicolumn{2}{|c|}{$\begin{array}{l}\text { Flammability Limits } \\
\text { (Vol. \% fuel in air) }\end{array}$} & \multicolumn{2}{|c|}{ Boiling Point } & \multicolumn{2}{|c|}{ Specific Gravity (Air) } \\
\hline & ${ }^{\circ} \mathbf{C}$ & ${ }^{\circ} \mathbf{F}$ & LFL & UFL & ${ }^{\circ} \mathbf{C}$ & ${ }^{\circ} \mathbf{F}$ & $\begin{array}{l}\text { Vapor } \\
\text { Density } \\
(\text { air }=1)\end{array}$ & $\begin{array}{c}\text { Min. Ignition } \\
\text { Energy } \\
(\mathrm{m} J)\end{array}$ \\
\hline Hydrogen & $400-572$ & $753-1061$ & 4.0 & 75.0 & -253 & -422 & 0.07 & 0.018 \\
\hline Natural gas (methane) & $632-650$ & 1169-1202 & 5.3 & 15.0 & -162 & -259 & 0.60 & 0.280 \\
\hline Propane & $450-493$ & $842-919$ & 2.2 & 9.5 & -42 & -44 & 1.56 & 0.250 \\
\hline
\end{tabular}

Obr. 8 Vlastnosti plynných paliv vozidel. [5]

Fig. 8 Properties of gaseóus fuels in motor vehicles. [5] 


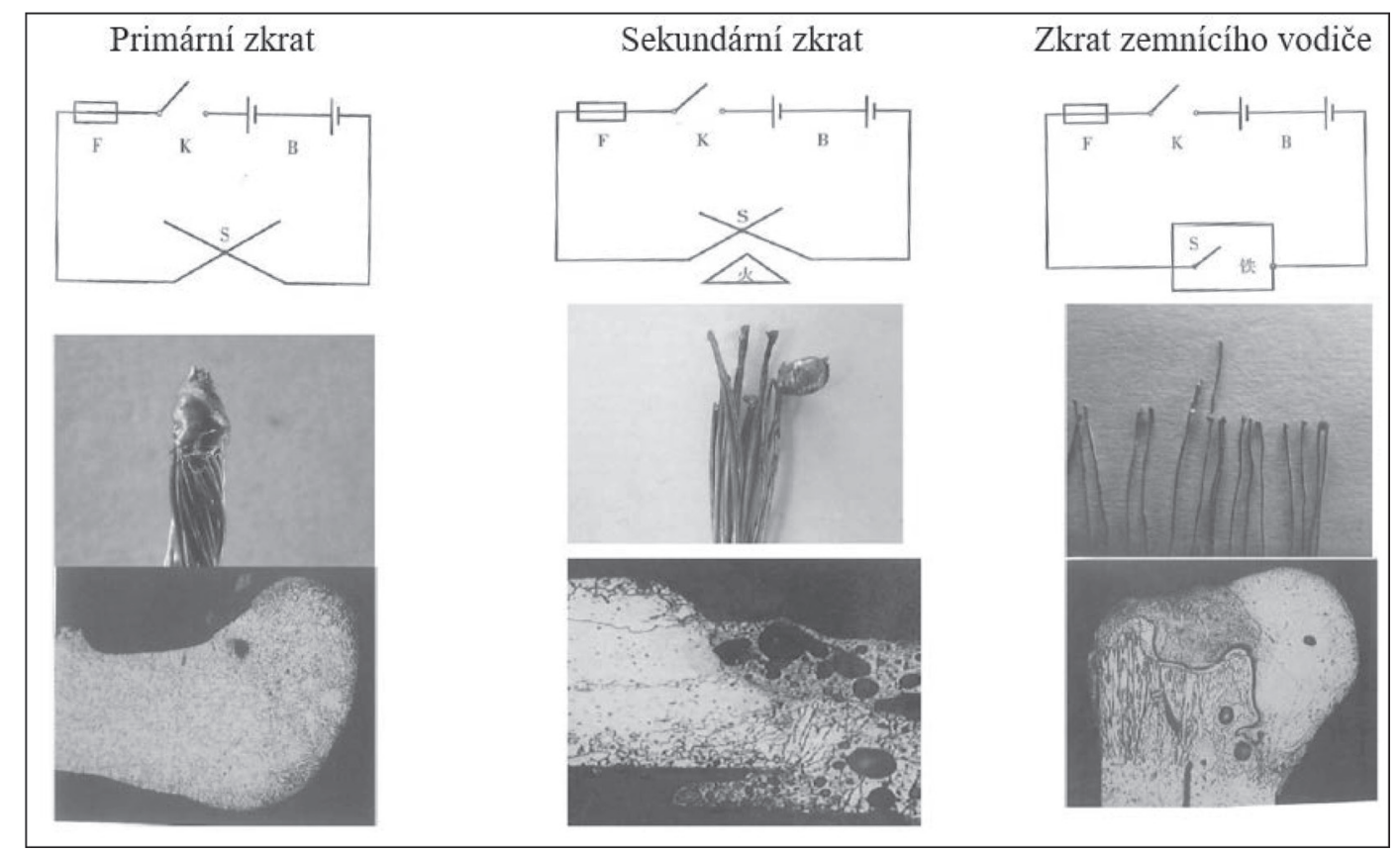

Obr. 9 Přiklady simulovaných elektrických zkratů 12V soustavy (zdroj: The Investigation of Vehicle Fire VWG od Hr. Liu Zhengang, Li, Jianlin, Geng, Huimin).

Fig. 9 Examples of simulated electrical short circuits of the $12 \mathrm{~V}$ system (source: The Investigation of Vehicle Fire VWG from Hr. Liu Zhengang, Li, Jianlin, Geng, Huimin).

systému. Tyto kapaliny se mohou zapálit během provozu nebo brzy po vypnutí motoru, pokud je teplota některých komponentů výfukového systému stále dostatečně zvýšená. Teploty vznícení tekutin na horkých površích jsou podstatně vyšší než stanovené teploty samovznícení. [4]

Následující faktory ovlivňují vznícení tekutin horkým povrchem:

- prísun vzduchu,

- faktory prostředí,

- bod samovznícení,

- bod vzplanutí kapaliny,

- bod varu tekutiny,

- rychlost odpařování kapaliny,

- rozprašování kapaliny (efektivní plocha paliva),

- teplota kapaliny,

- teplota povrchu.

Délka vystavení kapaliny na vyhřívaný povrch a konfiguraci horké plochy

Tyto faktory mohou ovlivnit poměr vzduchu a paliva $\mathrm{v}$ místě potenciálního zdroje vznícení a vytvářet směsi, které jsou bud' př́liš bohaté nebo př́liš chudé k zapálení a/nebo šíření ohně. Jiné hořlavé materiály, jako jsou plasty, papíry a vegetace, mohou dosáhnout své teploty vznícení při kontaktu s vyhřivanými součástmi vozidla. Katalyzátory běžně pracují s vnitřní teplotou blízkou $700{ }^{\circ} \mathrm{C}$ a povrchové teplotě blízké $315^{\circ} \mathrm{C}$, ale mohou být vystaveny vyšším teplotám při velkém zatížení, pokud je omezena cirkulace vzduchu nebo pokud nespálené palivo vstupuje dovnitř dílu kvưli přeplnění nebo nesprávnému zapalování motoru. Za takových extrémních okolností může být materiál keramické matrice uvnitř dílu poškozen.

Turbodmychadla lze nalézt na benzinových a dieselových motorech. Turbodmychadlo zvyšuje výkon motoru tím, že tlačí na tlakový vzduch do válců. Turbodmychadlo používá výfukové plyny k otáčení oběžného kola až do 100000 otáček. Turbodmychadla a výfukové potrubí, které je dodávají, jsou nejteplejšími body na povrchu motoru (při zatížení kolem $815^{\circ} \mathrm{C}$ ). Pokud dojde k úniku paliva nebo úniku oleje a tekutina se dostane do styku s těmito povrchy, mohou se paliva snadno vznítit. Středové ložisko většiny turbodmychadel je mazáno motorovým olejem pod tlakem. Pokud turbodmychadlo během provozu trpí mechanickým poškozením, může být motorový olej dodán do proudu horkého výfukového plynu, což může mít za následek požár. [4]

\subsubsection{Mechanické jiskry}

Mechanické jiskry vznikají při kontaktech kov-kov a mohou být spojeny s rotačním zařízením (alternátory, čerpadly, řemenice apod.) nebo ložiska. Kovový kontakt s vozovkou (např. poškozený hnací hřídel, ráfek pneumatiky nebo výfukové potrubí) může také způsobit jiskření. Vozidlo musí být v chodu nebo v pohybu, aby vytvořilo takový zdroj zapálení. Rychlost vozidla $8 \mathrm{~km} / \mathrm{h}$ byla určena $\mathrm{k}$ vytvoření jisker s teplotou $800^{\circ} \mathrm{C}$ a při vyšších rychlostech vznikly jiskry o teplotě $1200^{\circ} \mathrm{C}$. Jiskry kontaktu hliníku s vozovkou nejsou pro většinu materiálů považovány za možný zdroj zapálení. Obvykle tyto typy jisker nezapálí pevné látky. Je třeba věnovat pozornost palivům kolem oblasti, z níž vznikají jiskry, a časem, kdy jsou jiskry v kontaktu s těmito palivy.

Schopnost takových jisker zapálit jiné materiály je regulována poměrem jejich hmotnostního povrchu. Menší jiskry se ochlazují rychleji při vystavení okolnímu vzduchu. [4]

\subsubsection{Kuř́cké materiály}

Dalším zdrojem vznícení identifikovaným při požáru vozidel je nesprávné zneškodnění nebo zneužití kuřáckých materiálů. V hypotéze tohoto scénáře vznícení se zapalovací sekvence pro 
vyřazené kuřácké materiály soustřed'uje na schopnost vozidla omezovat a zadržovat teplo z kuřáckého materiálu a aspekty ventilace vozidla. Při posuzování možnosti takového vznícení je nutné respektovat předepsané hořlavostí součástí interiéru vozidla. Je nutno zvažovat vznícení jiných paliv, jako jsou papíry nebo oblečení ve vozidle. Pokud dojde k vznícení těchto materiálů, může se požár rozširriti i do jiných paliv, včetně materiálů ve vnitřním prostoru vozidla. [4]

\section{3 Šíření požáru - osobní vozidlo}

Jak již bylo zmíněno osobní vozidlo lze uvažovat jako zapouzdřenou konstrukci, kde požární děj se odehrává v rámci jeho fyzického stavu. Struktura požáru odpovídá spalovací reakci v průběhu času a síření plamene. Dle ložiska požáru se plamen a teplo šírí do dalších části konstrukce vozu. Po provedení hasebních prací šíření plamene a tepla nechává na konstrukci vozu vzory, jejich charakteristické znaky odpovídají fyzikální stavům a mohou pomoci lokalizovat zdroj vznícení.

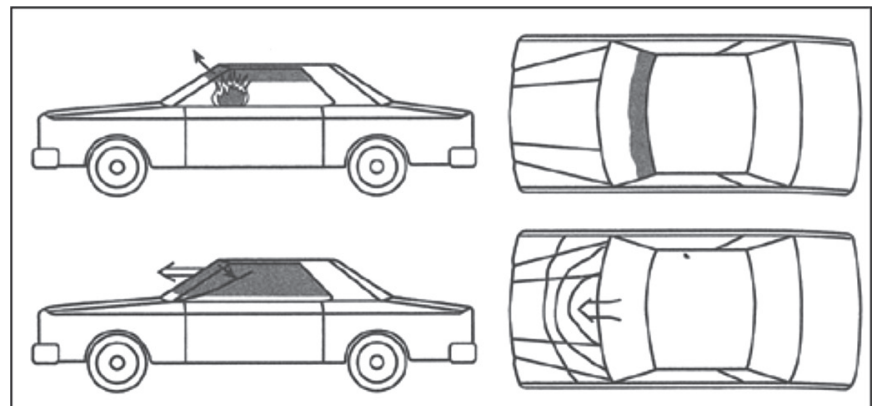

Obr. 10 Přiklad a vzory stop vývoje požáru z interiéru vozu. [5] Fig. 10 Fire pattern development from an interior origin. [5]

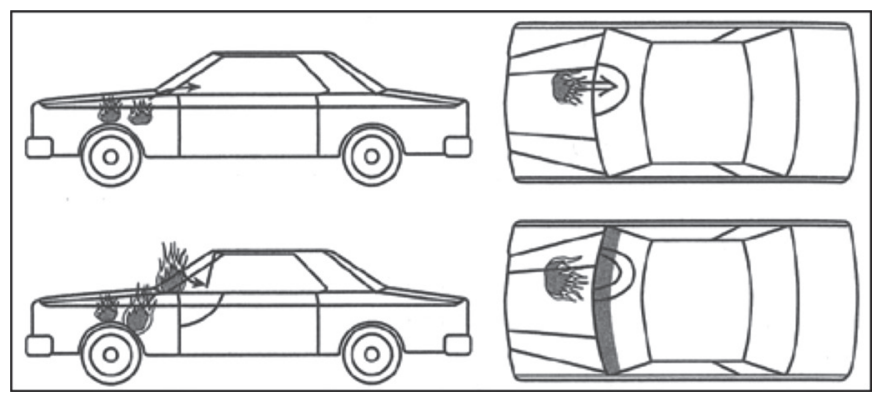

Obr. 11 Přiklad a vzory stop vývoje požáru z motorového prostoru vozu. [5]

Fig. 11 Fire pattern development from an engine compartment origin. [5]

Tam, kde existují zbývající vrstvy laku, hořlavé materiály (např. plastové obložení a pryž) a sklo, zkoumání exteriéru může odhalit významné vzory požáru, které mohou pomoci při určování prostoru požáru. Umístění ohně a způsob, jakým čelní sklo reaguje na něj, může umožnit určení původu prostoru šíření. Diagramy zobrazující potenciální vývoj požárního vzoru od prostoru zdroje původu jsou uvedeny na obr. 10 a 11. [5]

\subsection{1 Šírení požáru z interiéru vozu}

Oheň v prostoru interiéru vozu způsobí poškození v horní části čelního skla a ponechá na kapotě radiální vzory požáru (vzory

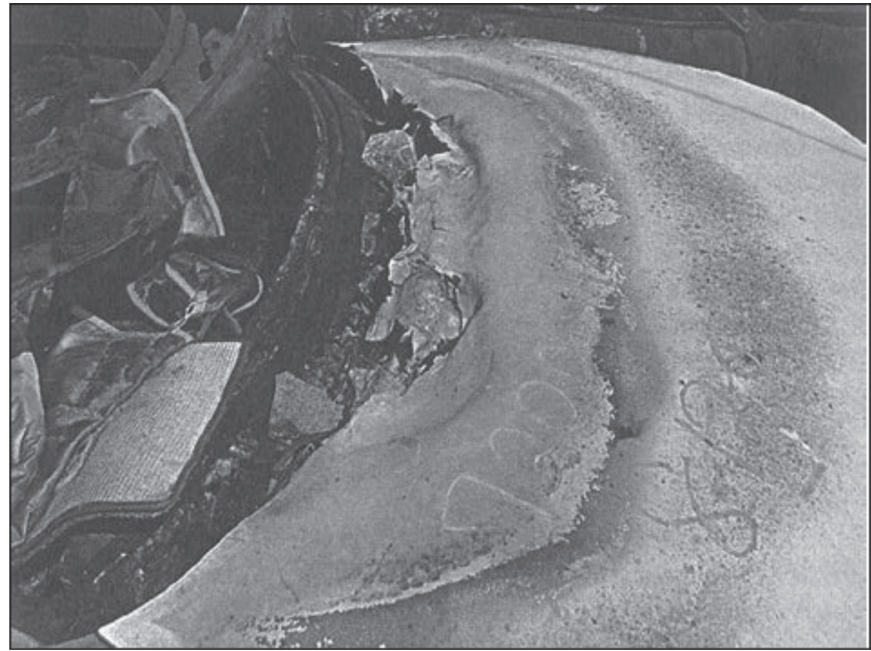

Obr. 12 Přiklad a radiálni stopy požáru z interiéru vozu. [5] Fig. 12 Radial fire pattern produced by a passenger compartment. [5]

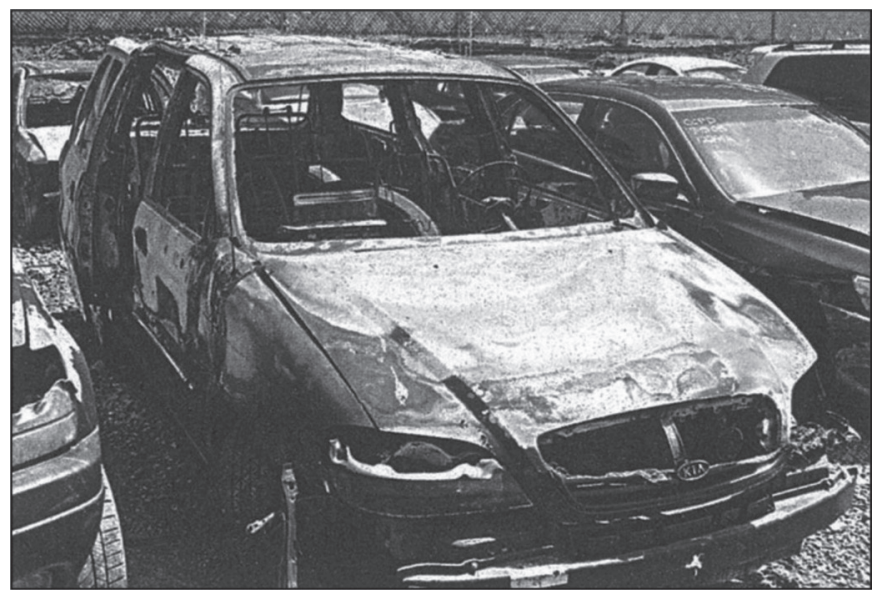

Obr. 13 Přiklad a radiálni stopy požáru z interiéru vozu. [5] Fig. 13 Radial fire pattern produced by a passenger compartment. [5]

požáru, radiálně vyzařované z oblasti původu). Tyto vzory se vytvářejí, jak postupuje oheň a spotřebuje povrchové vrstvy laku (obr. 12 a 13). [5]

Dalším př́íkladem jsou i radiální vzory z požáru interiéru vozu v zadní části vozu (obr. 14) a přední části (obr. 15). [5]

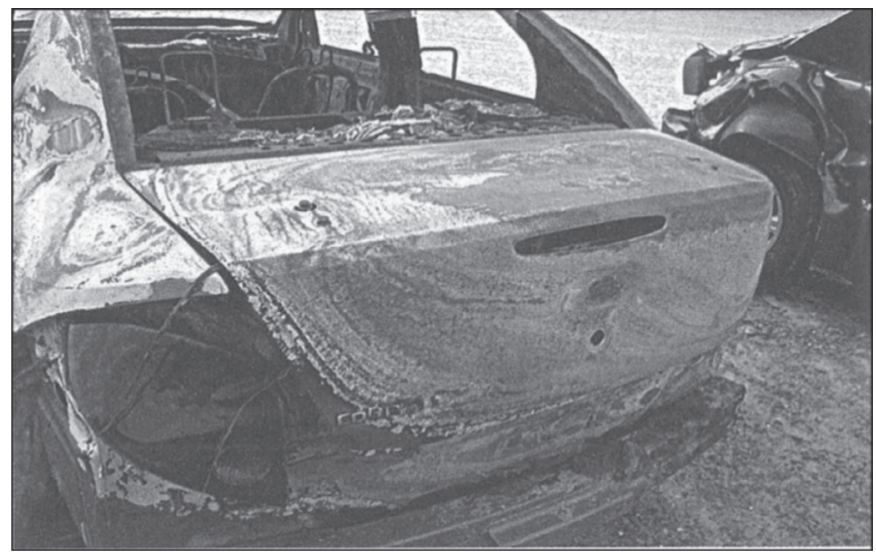

Obr. 14 Přiklad a radiálni stopy požáru z interiéru vozu. [5] Fig. 14 Radial fire pattern produced by a passenger compartment. [5] 


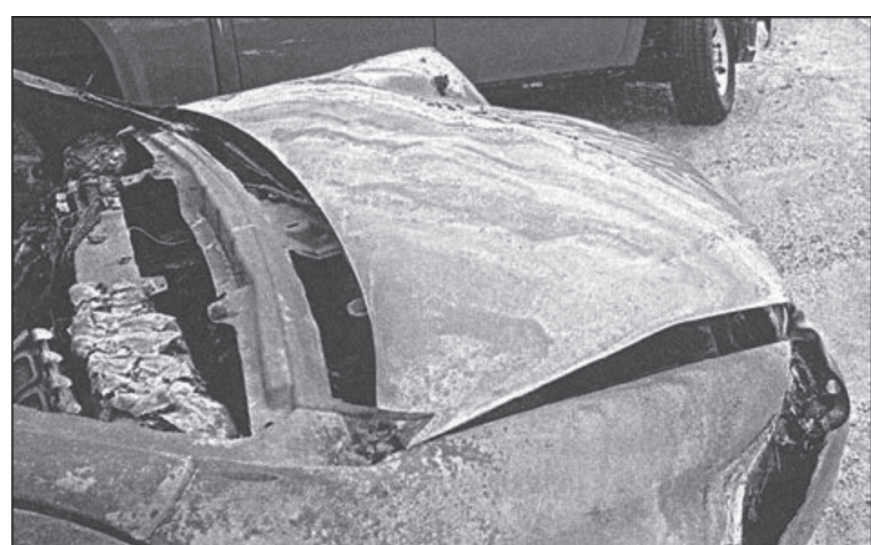

Obr. 15 Přiklad a radiální stopy požáru z interiéru vozu. [5] Fig. 15 Radial fire pattern produced by a passenger compartment. [5]

Rozdíly v barvách a vzorech na holých kovových plochách jsou časté při požáru vozidel, kdy byly spotřebovány většina, ne-li všechny vrstvy laku a další hořlavé materiály.

Je však třeba dbát opatrnosti, když se opíráte pouze o barvy a vzory na holých kovových površích bez podložených důkazů. Různé barvy mohou být způsobeny různými typy oxidů železa, které vznikly během požáru a po něm. Dokonce i jediný oxid může mít řadu barev v závislosti na jeho krystalické struktuře. Oxidové barevné variace mohou být také způsobeny změnami v typu a koncentraci nečistot na povrchu, legujících prvků a tloušt'ce oxidu. [5]

\subsection{2 Šírení požáru z motorového prostoru}

Požáry v motorovém prostoru se mohou rozšírit do prostoru pro cestující předcházejícími průniky přes přepážku motorového prostoru a obvykle způsobují poškození na spodní straně čelního skla v př́ípadě motoru umístěného v přední části vozu (obr. 16). [5]

Přepážka mezi motorovým prostorem a prostorem pro cestující je obvykle označována jako protipožární stěna. U moderních vozidel může mít tato přepážka mnoho průniků, některé spojení pro vytápění a klimatizaci, průchody elektroinstalace apod. Průchody

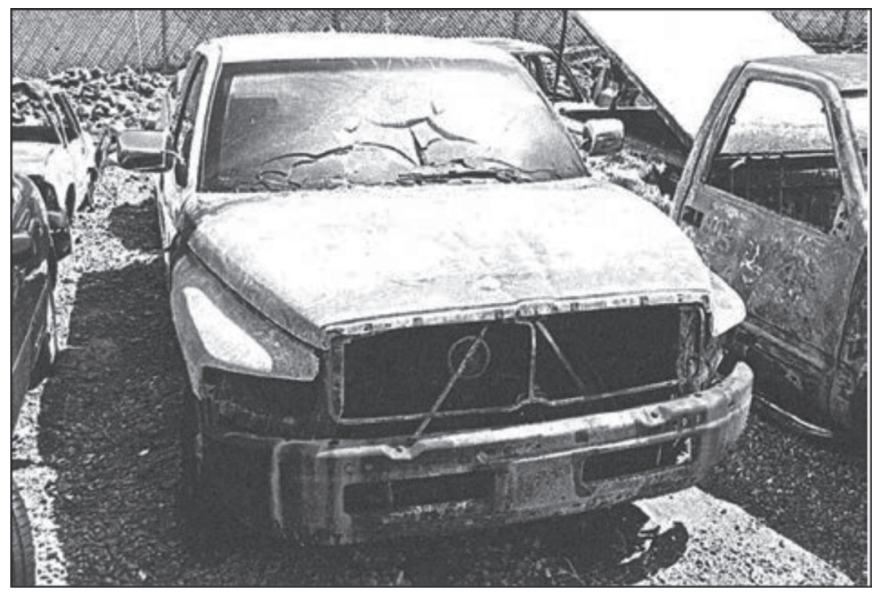

Obr. 16 Počáteční poškození čelního skla požárem z motorového prostoru. [5]

Fig. 16 Incipient windshield failure cause by an engine compartment fire. [5]

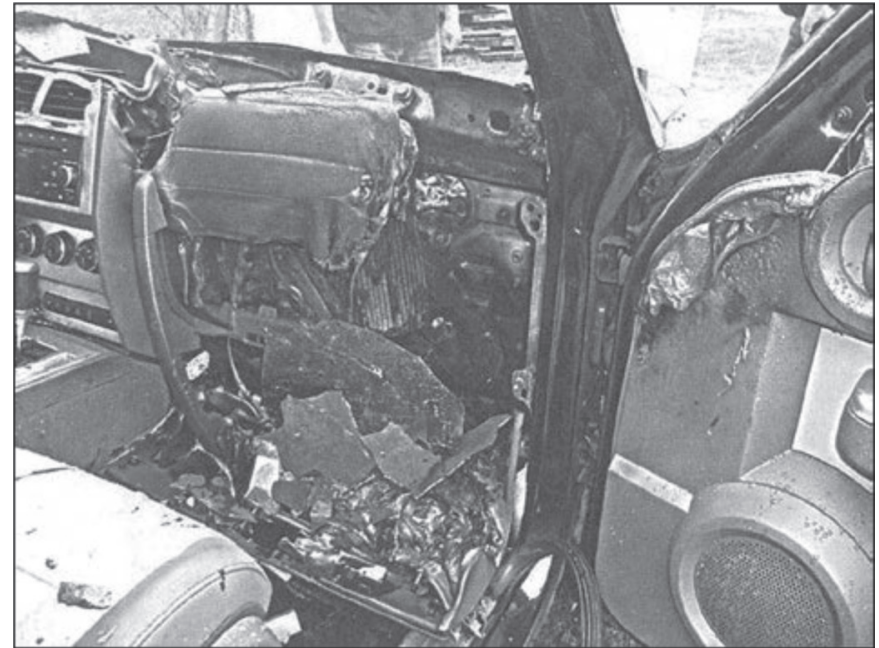

Obr. 17 Přiklad pri̊chodu požáru do interiéru voz z motorového prostoru. [5]

Fig. 17 Propagation of an engine compartment fire to the interior. [5]

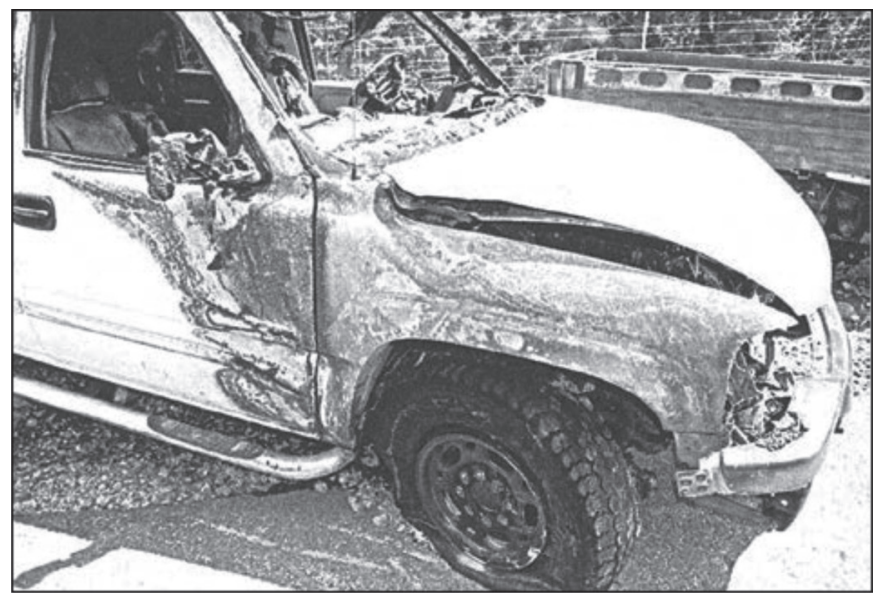

Obr. 18 Přiklad a radiální stopy požáru na dveřich spolujezdce způsobené požárem z motorového prostoru. [5]

Fig. 18 Radial pattern on the passenger's side door produced by an engine compartment fire. [5]

jsou obvykle zhotoveny z plastů, pryží a mohou hořet, což vede k rozšíření požáru do prostoru pro cestující. Požár se může také šírit vedením přes kovovou přepážku na hořlavý materiál např. pod prístrojovou deskou (obr. 17). [5]

\subsection{3 Šírení požáru ze zavazadlového prostoru}

Dle konstrukčního řešení vozu v případě šíření požáru ze zavazadlového prostoru platí stejná pravidla, avšak za předpokladu menšího výskytu možného paliva požáru. V takovýchto případech je nutné dbát př́tomnost externích materiálů a možných zdrojů vznícení v převážených předmětech.

\subsection{Detekce akcelerantů hoření}

Kromě technické analýzy vozu a jeho dílů patř́ i k metodám zjišt'ování př́ičiny požáru vyhledávání možných iniciátorů a akcelerantů hoření nebo jejich zbytky, k čemuž lze použít např́iklad speciálně vycvičeného požárního psa nebo různé sofistikované přístroje. 


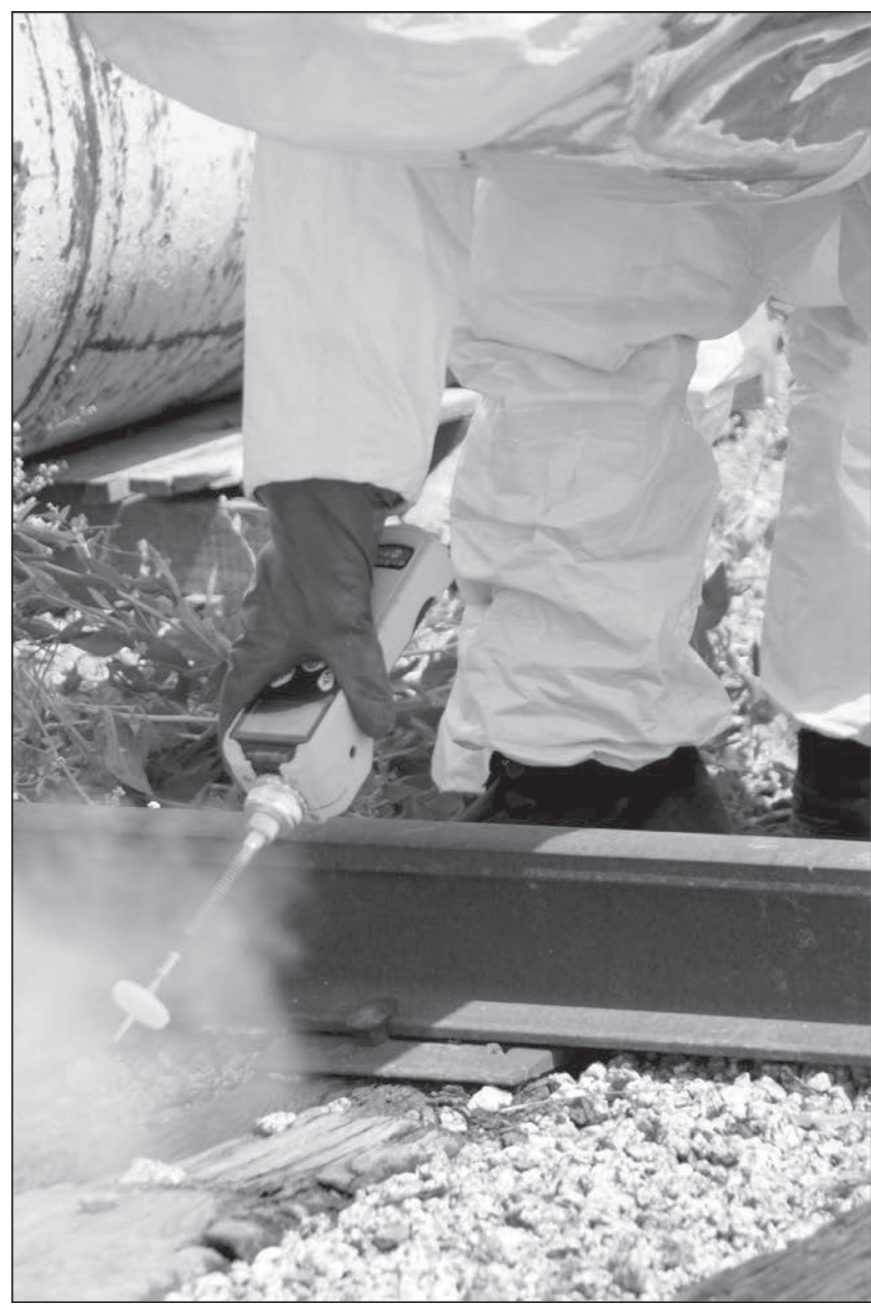

Obr. 19 MiniRAE 3000. (zdroj: RAE Systems MiniRAE 3000 Datasheet)

Fig. 19 MiniRAE 3000. (source: RAE Systems MiniRAE 3000 Datasheet)

Z hlediska vyhodnocení odezvy př́stroje a typu výstupního signálu se prostředky chemického průzkumu dělí na:

- jednoduché detekční prostředky (detekční trubičky),

- univerzální detektory,

- analyzátory.

V rámci ohledání vozu se v praxi, vzhledem k mobilitě a rychlé odezvě, osvědčují fotoionizační detektory. U těchto detektorů vzorek vzduchu s hořlavou látkou je nasáván čerpadlem přes filtr do ionizační komůrky, kde dochází $\mathrm{k}$ ionizaci molekul látky účinkem fotonů vyzařovaných z UV (ultrafialové záření) výbojky, což se projeví vznikem elektrického náboje. Vlastní senzor detekuje vzniklý náboj ionizovaného plynu a ten je převeden na elektrický proud. Proud je zesílen a převeden na koncentraci v jednotkách např. ppm (z angl. Parts per million - dílů či částic na jeden milion).

Ionizace plynu je však podmíněna skutečností, že ionizační potenciál sledované sloučeniny bude menší než energie fotonů vyzařovaných použitou UV výbojkou. [7, 8]

Typizovaný představitel je př́stroj společnosti RAE Systems MiniRAE 3000 (obr. 19), který se vyznačuje minimálními rozměry a hmotností, vestavěnými kalibracemi organických látek, vysokou

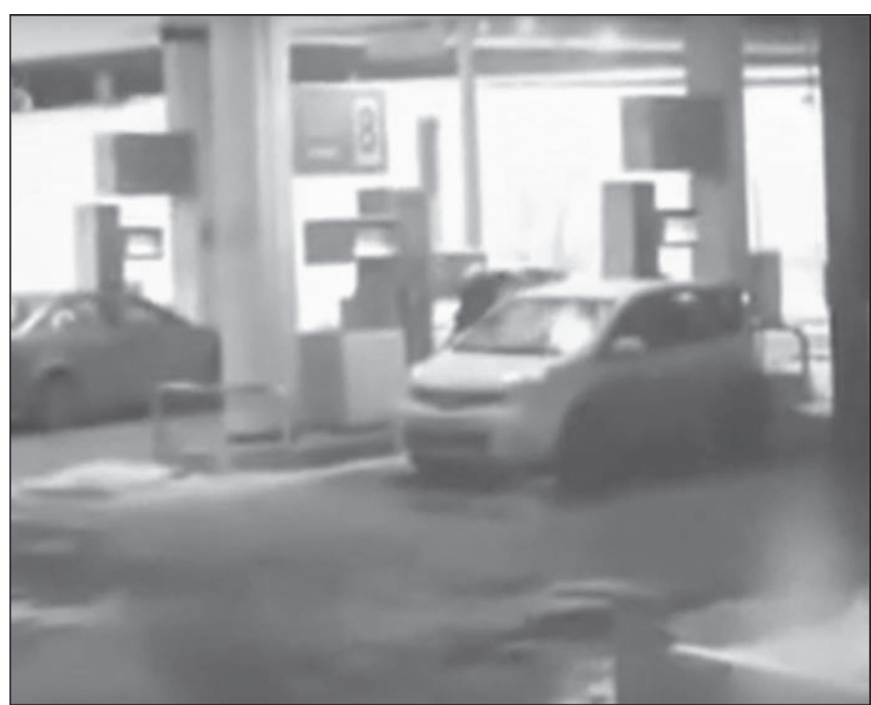

Obr. 20 Žena myjící čelní sklo benzínem na čerpací stanici. (zdroj: https://www.youtube.com/watch? $v=$ PPJvk6KEfyM)

Fig. 20 Woman washing windshield with petrol at a gas station. (source: https://www.youtube.com/watch? $v=$ PPJvk6KEfyM)

citlivostí a mimořádně jednoduchou obsluhou zabezpečovanou třemi tlačítky.

Použití fotoionizačního detektoru v rámci zjištění příčiny požáru osobního vozu má však také své limity, z důvodu velkého množství interferujících sloučenin, především množství těkavých látek a ropných produktů používaných $\mathrm{v}$ automobilech viz kap. 2.2.1. zároveň dobou expozice vozidla povětrnostním podmínkám po ukončení hasebních prací.

Použitím detektoru, při zachování logického možného výskytu těchto látek, lze však určit výskyt iniciátorů a akcelerantů hoření v provozně netypických místech vozidla (obr. 20).

\section{ZÁVĚR}

Článek pojednává, z dostupných zdrojů a vybraných materiálů, základní problematiku a metody spojené s vyšetřováním požárů osobních vozidel. Vychází především z informací odborných pracovišt' a anglických textů publikací vydané International Association of Fire Chiefs, Internation Association of Arson Investigators a National Fire Protection Association. Účelem bylo sjednocení základních informací týkající předpokladů k určení př́činy a obecného podvědomí možnosti lokalizace zdroje vznícení a šiření požáru u osobního vozu.

Určování konkrétních příčin přináší výzvu u každého jednotlivého případu požáru vozu, analýza a vyšetřování v době po události spoléhá především na zkušenosti vyšetřovatele rozpoznat a vybrat důležité aspekty u poškozeného vozu k zajištění určitých stop a důkazů $\mathrm{k}$ vyvození patřičného závěru.

\section{LITERATURA}

[1] HZS ČR: Popis fungováni procesu státního požárního dozoruzjištováni príčin vzniku požárů. Dostupné z WWW: https://www. 
hzscr.cz/clanek/popis-fungovani-procesu-statniho-pozarnihodozoru-zjistovani-pricin-vzniku-pozaru.aspx.

[2] HZS ČR: Zjištování př́čin vzniku požárů. Dostupné z WWW: https://www.hzscr.cz/clanek/hzs-stredoceskeho-kraje-menupozarni-prevence-zjistovani-pricin-pozaru-zjistovani-pricinvzniku-pozaru.aspx

[3] HACSIKOVÁ, V. Proč vznikaji požáry vozidel? Nejčastějši př́činou je technická závada, požár ale může vzniknout i po dopravni nehodè. 2014. Dostupné z WWW: https://www. pozary.cz/clanek/99103-proc-vznikaji-pozary-vozidel-nejcastejsipricinou-je-technicka-zavada-pozar-ale-muze-vzniknout-i-podopravni-nehode/

[4] KOLEKTIV AUTORŮ. International Association of Arson Investigators Staff: Principles and Practice to NFPA 921 and 1033. Fifth edition. Jones \& Bartlett Learning, LLC, 2018, Burlington, 528 s. ISBN 978-1-284-14074-3.

[5] KOLEKTIV AUTORŮ NFPA. NFPA 921: Guide for Fire and Explosion Investigation. NFPA, 2017, Quincy-Massachusetss 02169, 394 s. ISBN 978-1-4559-1602-3.
[6] BENÝŠEK, M. Požár osobního automobilu. 2012, ČVUT, Praha, 31 s. Dostupné z WWW: http://people.fsv.cvut.cz/ wald/ edu/134SEP_Seminar_IBS/2012/02_SP12_Benysek_Pozar_ automobilu.pdf

[7] PŘICHYSTAL, L. Nové metody použivané při zjištováni přičin vzniku požárů. VUT, Brno, 2011, 102 s. Dostupné z WWW: https://dspace.vutbr.cz/handle/11012/16808

[8] LINHART, P., ČAPOUN, T. Systém chemického prüzkumu a laboratorni kontroly v HZS ČR. Praha, 2005. 88 s. ISBN 80-86640-54-X.

[9] MARTÍNEK, M. Úvod do problematiky zjištování př́čin požárů osobních vozidel. In: Sbornik príspěvků konference Expert Forensic Science Brno 2019. VUT v Brně, 2019, s. 160-176. ISBN 978-80-214-5708-9.

\section{Správná citace:}

Martínek, M. Úvod do problematiky zjištování příčin požárů osobních vozidel. Soudní inženýrství, 2019, 30(3), $13-22$.

DOI: http://dx.doi.org./10.13164/SI.2019.3.13. ISSN 1211-443X. 